\title{
The Formation of Indicators on Engineering Laboratory Management
}

\author{
Ruhizan M.Yasin ${ }^{1}$, Zunuwanas Mohamad ${ }^{1}$, Mohd Nizam Ab. Rahman ${ }^{1} \&$ Mohamad Hisyam Mohd Hashim ${ }^{2}$ \\ ${ }^{1}$ Faculty of Education, Universiti Kebangsaan Malaysia, Malaysia \\ ${ }^{2}$ Faculty of Technical and Vocational Education, University Tun Hussein Onn Malaysia, Malaysia \\ Correspondent: Mohamad Hisyam Mohd Hashim, Faculty of Technical and Vocational Education, University \\ Tun Hussein Onn Malaysia, Johor 86400, Malaysia. Tel: 60-137-770-161. E-mail: mhisyam@uthm.edu.my
}

Received: August 6, 2012 Accepted: August 13, 2012 Online Published: September 12, 2012

doi:10.5539/ies.v5n5p212 URL: http://dx.doi.org/10.5539/ies.v5n5p212

\begin{abstract}
This research is a developmental study of Engineering Laboratory Management indicators. It is formed to assess the level of quality management of the polytechnic level laboratory. The purpose of indicators is to help provide input into the management process of an engineering laboratory. Effectiveness of teaching and learning at technical institution, mostly depending on the teaching and learning strategies by the lecturer during lecture and practical work in the laboratory. The indicators were developed through four round of the Delphi study. Four clusters of indicators have been identified namely documentation management, safety, environment and equipment. Good management of the laboratory is to ensure that facilities and hardware in good condition, safe and reliable, instruments must be accurate, consistent and can be detected, as well as teaching and learning activities carried out with guaranteed quality and accountability. The results should provide input to the Board of Engineers Malaysia (BEM) where it sets out the requirements of Engineering Studies program at the Institute of Higher Education. It is suggested that the emphasis of the quality should also include laboratory management as well as training and project development with industry to get recognition.
\end{abstract}

Keywords: laboratory management, quality management, facilities management, safety management, delphi study, engineering laboratory

\section{Introduction}

Polytechnics Management Department (IRD) has developed a transformation plan in an effort to upgrade polytechnic to a university in 2015. This is the right platform for polytechnic to move forward as leading technical and vocational fields in the country. It is also inline with the higher education minister goal that stated in its strategic plan: "The goal of the National Higher Education Strategic Plan (PSPTN) is consistent with the objectives of the National Mission, to develop and build human capital and quality intellectual capital for the success of Malaysia's aspirations for a progressive, prosperous and competitive nation". This goal is translated into the Annual Report of the Management Department of Polytechnic and Community College (2006) that states "the quality policy of the management of polytechnics are to develop the potential polytechnic students of Malaysia Ministry of Higher Education for excellence in engineering, commercial and hospitality through the comprehensive and continuous improvement". Hence all these vision should be taken through every aspect of polytechnic management system not excluded the practical teaching and learning in the laboratory.

Laboratory management involves many parties who directly used laboratory. Engineering laboratories are usually managed by a laboratory coordinator who is normally a lecturer and assisted by laboratory technicians. The responsibility is mainly on the laboratory coordinator to ensure that all documentation, facilities, safety, environment, equipments and materials of practical work are in good condition and adequate. Lokman (1997) found that these management activities encompass all aspects of planning, implementing, organizing, evaluating, directing, coordinating and controlling. Knowledge and high skills and experience relevant to the management of laboratory work can help lecturers perform good and perfect process of teaching and practical.

\section{Quality Engineering Education through Laboratory Management}

The field of engineering education is an area that has become a priority in the education sector in the country. There are many engineering courses offered by universities, institutes, and colleges through out the world. The laboratory is a key component in learning for engineering program. 
According to Azizi (2008), that the factor of safety, equipment, environment and management effectiveness influenced the teaching and learning in the workshop. Practical requirement for quality management systems in engineering is to ensure quality education services which are able to produce graduates who are competent and competitive at the global market. Quality education services include the provision of infrastructure and personnel involved in the process of education (Khoo 2004). While Zulfadly Mohd Othman (2011) describes the transformation of technical and vocational education is a priority in many developing countries as an alternative to adopting the changes of globalization. Furthermore Muhammad Afzamiman Ariffin (2011) also discussed the direction of technical and vocational education in comparison to Avicenna Integration methods and concepts for all. While the studies by Lee and Kokin (1997), Dennis (1970), Patrick (1998) also discussed the need to improve the quality of training to achieve greater educational skills as Tommy (1998) relates the elements of quality requirements in the training program implemented in Hong Kong. Findings by Mason (1991) suggests three propositions that can guide the thinking of the concept with the principles of quality which are individual attention to quality, organizational goals and the appropriate management system to determine and coordinate the work. Further management systems need to be addressed despite an increase in quality and quality improvement efforts in organizing the project that provides a great benefit to improving quality.

Management-related laboratories research by Charles (1995), Clinton (1998), Nurzatulshima (2009) stated management means how to make things work. Each administrator and leadership need to understand the management process to provide maximum benefit to the organization. According to Geoffrey (1996) that there are five state-of-service quality dimensions, namely: i) tangibles (physical facilities, equipments, appearance of personnel) ii) reliability (ability to perform the service promised dependly and accurately) iii) responsiveness (willingness to help and provide prompt service) iv) assurance (knowledge and courtecy of employess and ability to inspire confidence v) empathy (caring, individualized attention the firm provide its customers). Furthermore, Homberg \& Bakshi (1982) viewed practical work activities as a continuous work. Quality of laboratory work is a crucial element in the procedures of ensuring that all laboratory practices complied with by staff and students. According to Md. Nazri (2004) workshop (laboratory) is the place to do practical work and understanding theory. According to Armstrong (1999) who states that there are four steps that must be observed in the management goal that can be implemented in the best way are to use resources effectively and planning, organizing, and controlling motivation. Maslina (2008) stated that accident can occur unexpectedly, thus safety elert is a condition that should always be in the forefront in any management system. Accidents can cause injury to persons, damage to property or equipment and so on. Study by Stephen (1999) found safety in the workplace or laboratory is a branch of management. It should be designed and planned to reduce possible impact of accidents on the employee or student. According to Nurzatulshima (2008) safety management plan covers how accident prevention coordinator, security and the action taken in the event of an accident in the laboratory.

Findings by Kelly (2010) described the formal documentation system for recording information on all related laboratory activities. This is important for the purpose of practical work, as a reference, in case of accident investigation, for analysis and reporting (tables, manuals, plans, or computer) as well as it is necessary to facilitate the operations of all maintenance management. Mohd Hazwan (2006) considered the documentation can also be a source of reference for job growth in the near future. The documentation can facilitate the work done as a complete history of the laboratory when it being updated over time. According to safety procedure, the documentation is not a practical course of things, which can be taken for granted because it affects students and teaching staff if a matter goes wrong. To ensure the success of safety programmes, especially in the engineering lab, there are three regulations that must be observed, namely (i) always concerned about security problems or potential problems (ii) must take action in the event and provide an action plan (iii) constantly reinforce safety planning. A plan will be difficult when students fail to understand the procedures and take action of the accident. The study by Yun and Stanley (2004) discussed the importance of inventory management system to increase the level of laboratory management. Safety must be a culture in laboratory practices for example keeping laboratory environment neat of high level and at all times to ensure that no harm occurred as a result of various factors such as slips, falls and so on. Equipments or facilities management is also part of the laboratory management. According to Hasley (2002) that information on equipment is needed in planning a practical method, and it is also supported by Chin (2003) that explained the teaching of knowledge related to type of equipment and how to use it could help students carry out practical work smoothly. According to Goetsch (2005) accident prevention and industrial safety was first introduced by Herbert W.Heinrich who discovered four main things which should be studied in greater detail in the laboratory management research namely: the documentation, safety, environment and equipment. Hence, laboratory management and maintenance can be operating in orderly. According to Mohamad (2012), the improvements to be performed by the laboratory management are aimed to ensure all parties directly involved in laboratory activities are satisfied with the quality of the laboratory 
management. Since several studies have been proven of the importance of the laboratory management but yet the continous effort to improve the system should be done continuously. Therefore this study is seems timely to revolutionized the system of managing the laboratory through empirical study and technological innovation to improve quality of teaching and learning in the laboratory of the polytechnics system in Malaysia.

\section{Methodology}

The Study was conducted using the Delphi technique to form a consensus group of indicators on engineering laboratories management. Fifteen experts in the field of laboratory management were interviewed to get to the agreed decision. Acording to Yasin et al. (2010), the Delphi technique is the best approach in forming indicators for a new framework because it involves more than one expert opinion. In this study, four round of study was conducted. The last round was determined when the result shows the saturated agreement. This is in accordance to the view of Ludwig (1997) and Bauder (1999), where round session was suspended at the fourth level is consistent with the stating the number of rounds in a Delphi study was stopped when the researcher to meet the requirements of the research goals. Round process will be stopped if a high level of consensus among experts has been achieved and the required information has been obtained or a prior agreement about the number of rounds has been completed successfully by the researcher. It is supported by Ewing (1991) and Jones (1999) which holds that the error predicting the future has begun to moderate in the second round and third sessions of the Delphi study.

\section{Finding and Discussion}

The findings from the interviews conducted from 15 expert panel Delphi study has produced four indicators and 15 features (elements) of laboratory management for lecturers and 14 features (elements) for students. The four indicators are:

- documentation management

- safety management

- environmental management

- equipment management.

While the 15 elements for the lecturers are:

- the implementation of quality

- planning practical work

- practical work preparation

- management recording

- recording equipment

- information security

- security management procedures

- training

- monitored security

- information management environment

- environmental management procedures

- environmental monitoring

- information management tools

- equipment management procedures

- actions

The element of training is only appears in the elements for the lecturer but not the student. All these factors are certainly needed to ensure the high quality maintainance of polytechnic laboratory in accordance to production skills to the students and verification of by external parties. The field of engineering education is an area that has become a priority in the education sector in the country. The classroom learning emphasizes on understanding of theories, while practical in the laboratory is the transfer and validation of theories and principles learned in class. In this regard, the preparation of laboratory learning needs to play a very important step for the students who study engineering. Various forms of measurement and evaluation can be employed in ensuring the quality of 
laboratory management to be implemented in accordance with established procedures. Quality service starts from the top (management).The dedication shown by staff from the management. Management must provide advice and training to customers and staff in especially in communication between all parties to form a better relationship. This is clearly reflected in the performance of laboratory work relations between lecturer, technician, department management and the students where everybody can help in the implementation of laboratory / workshop experiment with great success.

The laboratory is the place where evidence is obtained and used for the development of scientific concepts. Literatured showed that the laboratory is the place where the activities carried out can gather scientific evidence which enabled the field of science continues to grow. Indirect interest of usability and management of laboratory activities is to be given priority in ensuring that each laboratory lesson plans can be implemented in an orderly and organized manner. It seeks to explain the implications, particularly for lecturer's new curriculum implementation. Among the aspects given in the description of the curriculum orientation program is changing the curriculum content, equipment and additional facilities, knowledge and skills of lecturers, language used and the credit system. To emphasize the understanding of theory, facilitate solutions of the theory and principles learned in class, laboratory work should aim to encourage students to gainmanipulative skills, observational skills, the ability to interpret experimental data, and the ability to plan experiments. Practical in the laboratory or workshop can help students to acquire the skills in analyzing the phenomena, designing and developing a system.

Therefore the laboratory learning must be properly managed to enhance the transfer of learning of students happen in a conducive environment. In addition, the monitoring of all aspects of laboratory management can build the interest of students to study in the subject area as well as for advance in the future.

\section{Conclusion}

Engineering education excellence is certainly contributed by the quality of laboratory services and provision of equipment to meet the practical requirements of a teaching module. This is a yardstick for the quality of an engineering laboratory. Competencies and skills the students will prevail, partly as a result of laboratory work conducted in the laboratory. This is emphasized by external parties, particularly the industry who is constantly looking at the quality of skills shown by students during their industrial training or who will be taken as an employee. Quality hands-on is part of the determinant factor of the quality and skills of a student. Management features of the formation of this documentation are a crucial element. This can be seen clearly in which a panel of experts has seen interest from different angles, namely the implementation of assessment in accordance with quality procedures, planning each laboratory practical work by the management, recording and documenting each transaction in the laboratory and laboratory safety. This defines management as a process to achieve planning, harness, control commands to achieve a set goal. For the implementation of quality, areas of concern are the responsibility of coordinating the laboratory quality management process run smoothly, valued, immediate actions taken when any complaints occur and implemention of process improvements from time to time.

Planning structures and methods of implementation of the study serves as a guideline to achieve the empirical evidence to a quality manament of polytechnic laboratory. Overall, the laboratory management research is an indicator of innovation in developing a management indicator system for engineering laboratory. This is to ensure that those responsible in the management of the laboratory to perform the duties conferred on procedural set by the authority in assessing the quality. There is significant correlation between the constructs developed by the management in the polytechnic engineering laboratories and the findings of the expert panel in this study. However this study appear to be the most comprehensive study that provide detail elements which further will be developed for the purpose of innovative laboratory management system for the continuous improvement of the quality of the Malaysian politechnics.

\section{References}

Armstrong, M. (1999). How to be an even better manager. 5th Ed. London: Kagan Page.

Azizi Yahya, \& Siti Atiqah Saharudin. (2008). Faktor yang mempengaruhi keberkesanan pengajaran dan pembelajaran di dalam Bengkel Vokasional di dua buah sekolah menengah teknik di Negeri Sembilan. Journal PSM TQAH. Fakulti Pendidikan, Universiti Teknologi Malaysia.

Baunder, S. M. (1999). A competency requirements analysis for digital television engineers. Tesis sarjana yang tidak diterbitkan. University of Wisconsin-Stout.

Chin, C. (2003). Success in investigations. The Science Teacher, 70(2), 34-40. 
Clinton, et al. (1998). Why Organisation fail: the view the front line. Management Decision, 37(6), 503-513.

Dennis, R. H. (1997). Improving training quality in developing countries: towards greater instructional efficiency. International Journal of Manpower, 18(1), 99-118.

Ewing, D. M. (1991). Future competencies needed in the preparation of secretaries in the state of Illinois using the Delphi Technique. Tesis kedoktoran yang tidak diterbitkan, Universiti Illinois. Retrieved 3 Feb 2004. Dissertation Abstracts international, 52(7), 2379A. No. Panggilan UMI No. 9136588.

Geoffrey, S. (1996). Measuring service quality in a tertiary institution. Journal of Educational Administration, 34(1), 72-82. http://dx.doi.org/10.1108/09578239610107174

Goetsh, D. L. (2000). The safety and Health Handbook. New Jersey: Pearson Prentice Hall.

Hasley, L. (2002). First Year 101. The Science Teacher, 69(9), 26-29. Retrieved from http://www.sbe.org/pdf/Thesis.pdf (February 12, 2010)

Jones, J. E. (1979). A look in Future: The 2020 organization. Retrieved from http://www.improve.org.2020org.html (June 11, 2010)

Kelly, A. (2010). Maintenance Management Auditing: In search of Maintenance Management Excellent. New York: Industrial Press.

Khoo Chooi Sim, \& Razhan M. Idrus. (2004). A Study Quality Assurance Practices in the Universiti Sains Malaysia, Malaysia. Turkish Online Journal Education: TOJDE-January, 5(1), 131-139. Retrieved from http://usm.academia.edu/rozhanmidrus/Papers/161961/A_Study_of_Quality_Assurance_Practices_in_the_ Universiti_Sains_Malaysia_USM_Malaysia (February 11, 2011)

Laporan Tahunan. (2006). Bahagian Pengurusan Politeknik, Kementerian Pengajian Tinggi Malaysia.

Lee, Y. S., \& Kokin, L. (1997). Managing quality at an engineering maintenance centre: From QCC to ISO 9001 and beyond. Journal of quality and Realibility management, 14(2), 118-137.

Lokman Bin Ahmad. (1997). Pengurusan dan penyelenggaraan makmal Kemahiran Hidup Bersepadu(Kemahiran Manipulatif) di sekolah menengah daerah Kubang Pasu Kedah. Satu Tinjauan. Tesis Sarjana Muda. Fakulti Pendidikan Universiti Kebangsaan Malaysia.

Ludwig, B. (1997). Predicting the future have you considered using the Delphi methodology. Journal of extension, 35(5), 233-239. Retrieved from http://www.joe.org/joe/1997october/tt2.php (June 10, 2009)

Maslina Masrom, et al. (2008). Makmal komputer kenali dan tadbir. Skudai: University Teknologi Malaysia Press.

Mason, R. M. et al. (1991). Understanding quality in engineering service organizations. Technology Management Conferences. pp. 468-472.

Md.Nazri Darlu. (2004). Keberkesanan sistem pengurusan makmal/bengkel di Jabatan Kejuruteraan Elekrtik, Politeknik Johor Baru Berdasarkan pensijilan MS ISO 9002. Tesis Sarjana. Fakulti Pendidikan Teknikal, Kolej Universiti Tun Hussein Onn.

Mohd Hazwan Mohd Puad. (2006). Pendidikan amalan keselamatan di kalangan pensyarah di institut latihan perindustrian, Tesis Sarjana. Fakulti Pendidikan Teknikal, Kolej Universiti Tun Hussein Onn.

Mohd Zulfadly Othman \& Rohana Hamzah dan Amirmudin Udin. (2011). Dua Teras Satu Destinasi: Pelan reformasi Strategik PTV ke arah Pembangunan Sejagat. Journal of EduPess, 1, 258-270.

Muhammad Afzamiman Ariffin, Rohana Hamzah, Muhammad Zulfadly Othman, \& Ismail Sabri Norihan. (2011). Hala tuju pendidikan Teknik dan vokasional:integrasi kaedah avecienna dan konsep untuk semua. Journal Teknologi, 56, 151-160.

Nurzatulshima Kamaruddin. (2008). Pengurusan persekitaran pembelajaran kaedah amali oleh guru fizik berpengalaman dan novis. Tesis Doktor Falsafah. Universiti Kebangsaan Malaysia.

Patrick, D. (1998). The rhetoric and bureaucracy of quality management: A total questionable method?. Personel Review, 27(1), 5-19. http://dx.doi.org/10.1108/00483489810368521

Stephen M. D. (1999). Safe work practies for rapid prototyping. Rapid Prototyping Journal, 5(4), 161-163. http://dx.doi.org/10.1108/13552549910295479

Yasin, R. M, Rahman, M. N. A, Mohamad, \& Z, Rahman, S. (2010). Developing framework for intelligent laboratory management. Procedia-Social and Behavioral Sciences, 1194-1197. 
Yun, K., \& Stanley, B.G. (2004). Information inaccuracy in inventory system -stock loss and Stockout. Massachusetts Institut of Technology, Department of Mechanical Engineering, Laboratory for Manufacturing and Productivity, 23 August.

Zunuwanas Mohamad, Ruhizan Mohammad Yasin, \& Mohd Nizam Ab Rahman. (2012). Laboratory Quality Management Requirements of Engineering at the Polytechnics Ministry of Higher Education Malaysia. Journal of Education and Learning, 6(1), 59-64. 